\title{
KUALITAS FISIK ORGANOLEPTIS, HARDNESS DAN KADAR AIR PADA BERBAGAI PAKAN TERNAK BENTUK PELLET
}

\author{
ORGANOLEPTIC PHYSICAL QUALITY, HARDNESS AND MOISTURE CONTENT ON \\ VARIOUS ANIMAL FEED PELLETS
}

\author{
C. S. Utama, ${ }^{1}$ B. Sulistiyanto dan R. D. Rahmawati \\ Departemen Peternakan \\ Fakultas Peternakan dan Pertanian, Universitas Diponegoro, Semarang. \\ ${ }^{1)}$ korespondensi author: cahyasetyautama@gmail.com \\ Diterima: 1 Februari 2020, Direvisi: 28 Februari 2020, Disetujui: 20 Maret 2020
}

\begin{abstract}
ABSTRAK
Penelitian ini bertujuan mengevaluasi kualitas organoleptis, tingkat kekerasan pellet (hardness) dan kadar air berbagai pakan ternak bentuk pellet. Penelitian menggunakan metode diskriptif. Pakan pellet yang digunakan adalah 8 jenis pakan pellet dari berbagai jenis ternak yaitu; pakan pellet ayam petelur grower; pakan pellet ayam broiler starter; pakan pellet sapi potong; pakan pellet sapi perah; pakan pellet kuda; pakan pellet itik petelur; pakan pellet babi penggemukan dan pakan pellet domba penggemukan yang didapatkan dari berbagai kios pakan ternak di Jawa Tengah. Parameter yang diamati adalah kualitas fisik organoleptik, tingkat kekerasan (hardness) dan kadar air. Hasil pengujian menunjukkan bahwa uji fisik organoleptis, hardness dan kadar air sangat berpengaruh pada kualitas pakan pellet namun warna pellet cenderung tidak ada perbedaan. Kesimpulan penelitian ini adalah pengujian kualitas pakan pellet pada berbagai ternak dapat dilakukan secara fisik organoleptis, hardness dan kadar air.
\end{abstract}

Kata Kunci: fisik, organoleptis, kadar air, hardness, pellet

\begin{abstract}
This study aims to evaluate the organoleptic quality, hardness and the moisture content of various pelleted animal feeds. This research was uses descriptive method. The pellet feed used was 8 types of pellet feed from various types of livestock, namely; pellet feed for laying hens grower; starter broiler pellet feed; beef pellet feed; dairy cow feed pellets; horse pellet feed; pellet feed of laying ducks; pellet feed for fattening pigs and pellet for fattening sheep are obtained from various animal feed stalls in Central Java. The parameters observed were organoleptic, hardness and moisture content. The results showed that the organoleptic physical test, hardness and moisture content greatly affected the quality of the pellets, but the color of the pellets tended to have no difference. The conclusion of this research was that testing the quality of pellets in various livestock can be done physically, organoleptically, hardness and moisture content.
\end{abstract}

Keywords: physical, organoleptic, moisture content, hardness, pellets

Kualitas Fisik Organoleptis, Hardness dan Kadar Air Pada Berbagai Pakan Ternak Bentuk Pellet-Cahya S. 


\section{PENDAHULUAN}

Perkembangan industri peternakan saat ini sangat pesat dan diiringi oleh pembaharuan berbagai macam peralatan. Sarana penunjang produktivitas ternak diciptakan dengan berbasis teknologi. Bentuk pakan, warna, aroma dan manipulasi lainnya dibuat dalam rangka meningkatkan produktivitas ternak. Salah satu bentuk pakan ternak yang ada dipasaran adalah pellet. Pakan pellet diproses melalui proses pelleting yang merupakan proses pengepressan dan pembentukan bahan pakan bentuk mash menggunakan die dengan ukuran dan ketebalan tertentu (Colovic et al., 2010). Pelleting dilakukan dengan cara menggumpalkan bahan dengan bantuan alat mekanik dikombinasikan dengan kelembaban, tekanan dan suhu (Muramatsu et al., 2015). Pelleting merupakan proses hidrotermal yang berfungsi mengurangi jumlah mikroba yang ada didalam pakan, memudahkan penanganan pakan, meningkatkan palatabilitas dan mempertahankan kualitas pakan (Behnke, 1996; Susilawati dan Khairini, 2017). Tahapan pembuatan pellet antara lain pengolahan pendahuluan yang terdiri dari pencacahan, pengeringan dan penghalusan bahan, tahap kedua pencampuran, pencetakan, pendinginan dan pengeringan bahan, dan tahap ketiga sortasi, pengepakan dan penyimpanan dalam gudang (Krisnan dan Ginting, 2009).

Kualitas pellet dapat diukur secara fisik dan organoleptik. Kualitas fisik yaitu hardness dan durability sedangkan kualitas organoleptik adalah warna, tekstur serta aroma pellet (Ismi et al., 2017). Bentuk dan sifat fisik pellet dipengaruhi oleh jenis bahan yang digunakan, die, kadar air, tekanan dan metode setelah pengolahan serta penggunaan bahan pengikat/binder (Retnani et al., 2009; Rahmana et al., 2016; Nurhayatin dan
Puspitasari, 2017). Tingginya kadar air pada pellet akan menyebabkan tumbuhnya jamur dan kerusakan pellet (Ismi et al., 2017). Pada saat proses conditioning atau pemanasan dengan uap air menyebabkan pati menjadi gelatin, melalui proses gelatinisasi terjadi perekatan antar partikel bahan penyusun sehingga penampakan pellet menjadi kompak, tekstur dan kekerasan menjadi bagus. Lama penyimpanan dapat menurunkan kualitas fisik pakan, semakin lama pakan disimpan kualitas pakan akan menurun dan akan mudah hancur (Jaelani et al., 2016).

Kebaharuan dari penelitian ini adalah mengetahui kualitas pellet pada berbagai jenis ternak yang dijual di wilayah Jawa Tengah. Tujuan penelitian adalah mengevaluasi karakteristik fisik organoleptik, hardness dan kadar air pakan pellet dari berbagai peternakan yang berbeda di wilayah Jawa Tengah. Manfaat penelitian adalah memberikan wawasan kepada masyarakat mengenai karakteristik berbagai pakan pellet di wilayah Jawa Tengah.

\section{METODE PENELITIAN}

Materi yang digunakan dalam penelitian adalah 8 jenis pakan bentuk pellet dari berbagai jenis ternak antara lain, pakan pellet ayam petelur grower (P1); pakan pellet ayam broiler starter (P2); pakan pellet sapi potong (P3); pakan pellet sapi perah ( $\mathrm{P} 4)$; pakan pellet kuda (P5); pakan pellet itik petelur (P6); pakan pellet babi penggemukan (P7) dan pakan pellet domba penggemukan (P8). Penelitian menggunakan metode diskriptif. Parameter yang diamati adalah organoleptik, tingkat kekerasan (hardness) dan kadar air.

Pengujian fisik organoleptik merupakan metode pengujian suatu bahan menggunakan panca indera secara kualitatif. Pengujian organoleptik yang diamati adalah warna, tekstur dan bau. 
Pengujian fisik organoleptik dilaksanakan dengan memberikan kuesioner kepada 27 orang panelis semi terlatih berdasarkan standar nilai yang telah ditentukan. Standar nilai menurut Sulistyanto et al. (2016) dan Hidayah et al. (2017) yaitu:

- Indeks warna dengan skala yaitu: nilai gelap $=1$; coklat tua $=3$; coklat terang $=5$; terang $=7$

- Indeks tekstur dengan skala yaitu: keras sekali $=1$, keras $=3$; sedang $=5$; lunak $=7$

- Indeks bau dengan skala yaitu: bau menyengat $=1$; agak menyengat $=3$; menyengat $=5$; normal $=7$.

- Pengujian tingkat kekerasan pellet dilakukan dengan menggunakan alat pellet hardness tester
- Pengujian kadar air dengan alat grain moustire tester.

Pengolahan data dilakukan dengan menggunakan metode diskriptif. Data hasil penelitian disusun dalam bentuk tabel yang merupakan susunan data, kemudian diinterpretasikan sesuai dengan hasil pengamatan yang ada (Utama et al., 2018).

\section{HASIL PENELITIAN}

Uji Fisik Organoleptik Berbagai Pakan Pellet

Nilai organoleptik berbagai pakan pellet ternak disajikan pada Tabel 1

Tabel 1.

Rataan Hasil Organoleptik pada Berbagai Pakan Ternak Bentuk Pellet

\begin{tabular}{cccc}
\hline \hline \multirow{2}{*}{ Pakan Pellet } & \multicolumn{3}{c}{ Organoleptik } \\
\cline { 2 - 4 } & Warna & Tekstur & Bau \\
\hline P1 & $5,00 \pm 0,01$ & $5,00 \pm 0,01$ & $7,00 \pm 0,01$ \\
P2 & $5,00 \pm 0,01$ & $6,33 \pm 0,82$ & $5,00 \pm 1,41$ \\
P3 & $5,00 \pm 0,01$ & $6,33 \pm 0,82$ & $7,00 \pm 0,01$ \\
P4 & $5,00 \pm 0,01$ & $1,67 \pm 0,82$ & $3,67 \pm 0,82$ \\
P5 & $3,67 \pm 1,63$ & $5,67 \pm 0,82$ & $7,00 \pm 0,01$ \\
P6 & $3,67 \pm 1,63$ & $6, \pm 0,82$ & $5,67 \pm 0,82$ \\
P7 & $5,00 \pm 0,01$ & $5,67 \pm 0,82$ & $5,00 \pm 1,41$ \\
P8 & $5,00 \pm 0,01$ & $5,00 \pm 0,01$ & $7,00 \pm 0,01$ \\
\hline
\end{tabular}

Pengujian fisik organoleptik merupakan salah satu cara menguji kualitas pakan dengan menggunakan panca indera dan dapat diukur secara kuantitatif. Pengujian fisik organoleptik yang diamati adalah warna, tekstur dan bau. Perolehan data kuantitatif dilakukan dengan menggunakan metode scoring dengan melibatkan minimal 20 panelis semi terlatih. Tabel 1. menggambarkan bahwa semua pellet berwarna coklat terang (skor 5), tekstur pellet dominan sedang dan berbau menyengat dan normal bau pellet (khas).

\section{Uji Hardness Pakan Pellet}

Nilai hardness berbagai pakan ternak bentuk pellet disajikan pada Tabel 2. 
Tabel 2.

Rataan Hasil Hardness pada Berbagai Pakan Ternak Bentuk Pellet

\begin{tabular}{|c|c|}
\hline Pakan Pellet & Hardness \\
\hline & ------- $\left(\mathrm{kg} / \mathrm{m}^{3}\right)$------- \\
\hline $\mathrm{P} 1$ & $4,02 \pm 0,10$ \\
\hline $\mathrm{P} 2$ & $3,83 \pm 0,30$ \\
\hline P3 & $3,33 \pm 0,12$ \\
\hline $\mathrm{P} 4$ & $5,50 \pm 0,00$ \\
\hline P5 & $2,42 \pm 0,29$ \\
\hline P6 & $4,55 \pm 0,16$ \\
\hline P7 & $4,00 \pm 0,18$ \\
\hline P8 & $2,50 \pm 0,00$ \\
\hline
\end{tabular}

Pengujian tingkat kekerasan pakan dilaksanakan dengan diuji menggunakan alat pellet hardness tester. Pellet yang baik memiliki nilai hardness berkisar 3,92 sampai dengan 6,37. Kekerasan tersebut dipengaruhi oleh ukuran dan bahan pellet. Komposisi bahan pakan, binder/perekat yang digunakan dan proses conditioning merupakan faktor yang dapat mempengaruhi hardness.

\section{Uji Kadar Air Pakan Pellet}

Nilai kadar air pakan pellet disajikan pada Tabel 3.

Tabel 3.

Rataan Hasil Kadar Air pada Berbagai Pakan Ternak Bentuk Pellet

\begin{tabular}{cc}
\hline \hline Pakan Pellet & Kadar Air \\
\hline P1 & $13,98 \pm 0,16$ \\
P2 & $15,05 \pm 0,08$ \\
P3 & $13,72 \pm 0,27$ \\
P4 & $16,12 \pm 0,29$ \\
P5 & $7,78 \pm 0,03$ \\
P6 & $8,22 \pm 0,04$ \\
P7 & $12,30 \pm 0,05$ \\
P8 & $15,82 \pm 0,18$ \\
\hline
\end{tabular}

Pengujian kadar air menggunakan alat grain moustire tester. Kadar air pellet yang baik yaitu berkisar antara $12-14 \%$. Kadar air yang terlalu tinggi (diatas 15\%) akan menyebabkan penurunan kualitas mutu bahan pakan karena mudah terkontaminasi jamur dan bakteri, selain itu akan membuat tekstur pellet lunak. Kadar air yang terlalu rendah (dibawah $10 \%$ ) akan mempengaruhi tekstur dan kekerasan pellet sehingga pellet akan mudah hancur.

\section{Uji Organoleptik Berbagai Pakan Pellet Warna}

Berdasarkan Tabel 1, dapat diketahui bahwa berbagai pakan ternak bentuk pellet tidak memberikan pengaruh terhadap warna pellet. Warna pellet ditentukan dari bahan penyusun pellet (Retnani et al., 2009). Tidak adanya pengaruh dan perbedaan pada warna pellet diduga karena bahan penyusun pellet yang digunakan pada berbagai pakan ternak bentuk pellet relatif sama, sehingga akan 
menimbulkan warna yang sama pula. Warna merupakan salah satu pertimbangan penting dalam memilih suatu produk. Wulandari et al. (2017) menyatakan warna dikategorikan sebagai indikator respon yang paling cepat dan mudah dalam memberikan kesan terhadap produk. Dijelaskan lebih lanjut oleh Hidayah et al. (2017) bahwa warna produk yang baik adalah warna yang tidak jauh berbeda dengan bahan asalnya. Semakin produk berwarna coklat tua atau kehitaman maka kualitas tersebut semakin rendah (Prabowo et al., 2013).

Warna pakan pellet dari berbagai macam ternak cenderung berwarna coklat terang. Hal ini menunjukkan bahwa warna yang baik dalam pakan ternak bentuk pellet berwarna coklat terang. Rakhmawati et al. (2017) menyatakan bahwa pellet yang memiliki warna terang tanpa bercak termasuk kategori pellet yang baik. Dijelaskan lebih lanjut oleh Ahmad (2009) bahwa adanya penyimpangan warna disebabkan adanya jamur dan kapang yang menyebabkan pakan tersebut memiliki warna yang beragam seperti kehijauan hingga cenderung coklat kegelapan.

\section{Tekstur}

Nilai tekstur yang terendah hingga yang tertinggi secara berurutan adalah 1,$67 ; 5 ; 5 ; 5,67 ; 5,67 ; 6,33 ; 6,33$ dan 6,33 (Tabel 1). Pellet sapi perah (P4) berbeda dengan pakan pellet yang lain. Hal ini disebabkan karena pellet sapi perah memiliki nilai hardness yang tinggi sehingga menyebabkan tekstur pellet menjadi keras. Selain itu, tekstur keras diduga disebabkan kandungan serat kasar pada pakan tersebut. Pakan pellet sapi perah menggunakan campuran hijauan dimana diketahui bahwa hijauan memiliki kandungan serat kasar yang tinggi. Midayanto dan Yuwono (2014) menyatakan tekstur merupakan ciri suatu bahan sebagai akibat perpaduan dari beberapa sifat fisik yang meliputi ukuran, bentuk, jumlah dan unsur-unsur pembentukan bahan yang dapat dirasakan oleh indera peraba dan perasa. Tekstur dapat dipengaruhi oleh bahan yang digunakan. Siregar et al. (2015) menyatakan bahwa perubahan tekstur pada suatu produk dapat ditentukan oleh komponen alami pada bahan itu sendiri seperti air, lemak, protein dan karbohidrat. Tekstur yang baik pada produk adalah tidak menggumpal, lembek dan tidak berlendir (Alvianto et al., 2015).

Pendugaan lainnya dimungkinkan kandungan pakan pada pellet sapi perah mengandung kandungan pati yang tinggi, sehingga akan mengikat secara alami senyawa-senyawa yang ada didalamnya. Pati merupakan bahan perekat alami yang dapat digunakan dalam proses pelleting. Menurut Juniyanto et al. (2013) tingkat kekerasan pakan dapat dilihat melalui ada atau tidaknya kandungan pati yang ada didalamnya, karena pati berfungsi sebagai bahan perekat alami saat proses pelleting. Pati tersusun dari dua macam karbohidrat yaitu amilosa dan amilopektin dalam komposisi yang berbeda-beda. Amilosa memberikan sifat keras (pera), sedangkan amilopektin menyebabkan sifat lengket. Kekerasan pellet mempunyai variasi yang lebar yang disebabkan oleh beberapa hal, yaitu; variasi panjang pellet. Pellet yang panjang memerlukan pemecahan yang lebih besar dibanding pellet yang lebih pendek. Kedua, adalah adanya keretakan pada pellet. Keretakan pellet disebabkan karena kompresi/tekanan yang diterima oleh bahan selama proses pembuatan pellet berbeda-beda. Pellet yang bagus mempunyai tingkat kekerasan yang tidak terlalu keras ataupun lunak (Ilmiawan et al., 2015).

Kualitas pellet dapat dilihat melalui bentuk fisik pakan tersebut yaitu pengamatan pada permukaan pakan pellet. Hal tersebut sesuai dengan pendapat 
Aslamyah dan Karim (2012) yang menyatakan bahwa faktor yang dapat menyebabkan kerasnya tekstur pada pakan pellet yaitu bahan perekat yang dapat dilihat dari bentuk permukaan pakan yaitu kemulusan, serat dan ada atau tidaknya lubang. Ismi et al. (2017) menyatakan bahwa tekstur pakan dipengaruhi oleh kehalusan bahan baku, jumlah serat dan jenis bahan pengikat. Faktor lain yang dapat mempengaruhi tekstur pellet adalah proses pelleting. Akbar et al. (2017) melaporkan bahwa proses pelleting yang baik menyebabkan nilai derajat kehalusan yang tinggi sehingga ukuran partikelnya lebih besar dan cenderung lunak.

Pellet yang baik memiliki tekstur halus dan tidak mudah retak, hal tersebut akan membuat pellet tahan terhadap benturan dan tidak mudah hancur ketika dilakukan penumpukan pakan. Nurhayatin dan Puspitasari (2017) menyatakan bahwa pellet yang baik berbentuk kompak dengan tekstur halus, tidak mudah retak dan keras. Krisnan dan Ginting (2009) menyatakan bahwa tekstur pakan yang kompak akan tahan terhadap pengaruh proses penekanan sehingga ikatan antar partikel penyusun pakan menjadi sangat kuat dan ruang antar partikel bahan tidak terisi rongga udara.

\section{Bau}

Nilai bau dari yang terendah hingga yang tertinggi secara berurutan adalah 3,67 (P4); 5,00 (P2); 5,00 (P7); 5,67 (P6); 7,00 (P1); 7,00 (P3); 7,00 (P5) dan 7,00 (P8). Nilai bau terendah pada penelitian ini adalah pellet sapi perah. Nilai bau yang rendah menjelaskan bau pakan tersebut memiliki bau yang menyengat (apek). Bau yang dihasilkan dari indikasi banyak atau sedikitnya aktivitas mikroorganisme yang terkandung didalamnya. Aktivitas mikroba tersebut biasanya terjadi pada pakan yang mengandung kadar air yang tinggi. Hal ini menjelaskan bau pellet sapi perah yang menyengat diduga diakibatkan karena kandungan air pada pellet tinggi. Menurut Solihin et al. (2015), kadar air pakan yang tinggi akan menyebabkan aktivitas mikroorganisme sehingga menyebabkan perubahan aroma pada pakan. Wulandari et al. (2017) menyatakan aroma juga sering digunakan sebagai parameter untuk menentukan baik atau buruknya kualitas produk yang dihasilkan. Alviato et al. (2015) dan Kurniawan et al. (2016) menyatakan bahwa perubahan aroma juga disebabkan oleh bakteri yang merubah senyawa kompleks menjadi lebih sederhana. Bau pellet yang baik adalah bau yang menyerupai bahan baku pembuatan pellet, berbau segar dan tidak tengik. Hal tersebut sesuai dengan pendapat Rakhmawati et al. (2017) yang menyatakan bahwa bau yang dihasilkan pada pellet merupakan bau dari bahan baku pellet. Ismi et al. (2017) menyatakan bahwa bau pellet yang baik adalah pellet yang memiliki bau segar dan tidak tengik. Faktor yang dapat mempengaruhi bau pellet adalah kadar air, lemak dan protein. Hal tersebut sesuai dengan pendapat Widiyastuti et al. (2004) yang menyatakan bahwa bau pada pellet dipengaruhi oleh kandungan kadar air, lemak dan protein pada pakan.

\section{Uji Hardness Pakan Pellet}

Nilai hardness dari terkecil ke yang tertinggi secara berurutan adalah $2,42 \pm 0,29 \mathrm{~kg} / \mathrm{m}^{3}$ (P5), 2,50 $\pm 0,00 \mathrm{~kg} / \mathrm{m}^{3}$ (P8), 3,33 $\pm 0,12 \mathrm{~kg} / \mathrm{m}^{3}$ (P3), 3,83 $\pm 0,30$ $\mathrm{kg} / \mathrm{m}^{3} \quad(\mathrm{P} 2), \quad 4,00 \pm 0,18 \quad \mathrm{~kg} / \mathrm{m}^{3} \quad(\mathrm{P} 7)$, $4,02 \pm 0,10 \mathrm{~kg} / \mathrm{m}^{3}(\mathrm{P} 1), 4,55 \pm 0,16 \mathrm{~kg} / \mathrm{m}^{3}$ (P6) dan $5,50 \pm 0,00 \mathrm{~kg} / \mathrm{m}^{3}$ (P4).

Nilai tertinggi hardness adalah pellet sapi perah. Salah satu yang mempengaruhi hardness adalah bahan pakan penyusun pellet tersebut. Pendugaan yang menyebabkan adanya perbedaan dari pellet sapi perah adalah 
serat kasar, kandungan pati dan protein yang lebih tinggi dari jenis pakan pellet yang lain. Menurut Juniyanto et al. (2013), salah satu yang mempengaruhi tingkat kekerasan pakan adalah kandungan pati didalamnya, karena pati dapat berfungsi sebagai bahan perekat alami melalui proses gelatinisasi pada pellet saat proses pelleting. Selain kandungan pati, kandungan serat kasar pada bahan pakan penyusun pakan pellet juga dapat mempengaruhi hardness dari pakan pellet itu sendiri. Ikatan serat yang dihasilkan dari serat kasar akan mengikat senyawasenyawa dari bahan pakan tersebut sehingga akan jarang sekali bahan pakan yang memiliki kandungan serat kasar yang tinggi memiliki tekstur yang tidak keras. Selain itu, kandungan pakan yang diberikan sapi perah mengandung kandungan serat kasar yang tinggi, karena pada dasarnya ternak ruminansia khususnya sapi perah merupakan ternak yang mampu mencerna serat kasar yang baik karena memiliki rumen yang mampu memfermentasikan serat kasar menjadi vollatyl fatty acid (VFA). Suhendra et al. (2015) menyatakan bahwa VFA akan dimanfaatkan sapi perah untuk prekusor pembentuk susu yaitu laktosa dan lemak.

Pellet yang baik memiliki nilai hardness berkisar 3,92 sampai dengan 6,37 . Hal tersebut dapat dipengaruhi oleh ukuran partikel pada pellet. Kaliyan dan Morey (2009) menyatakan bahwa kekerasan pellet minimum dengan diameter 4,0 - 5,0 adalah $3,92 \mathrm{~kg}$, sedangkan kekerasan dengan diameter 6,0 - 8,0 adalah 6,37 kg. Rakhmawati et al. (2017) menyatakan bahwa komposisi bahan, binder yang digunakan dan proses conditioning merupakan faktor yang dapat mempengaruhi hardness. Ukuran pellet yang besar memudahkan proses penanganan pada industri. Hal ini menurut Syamsu (2007) bahwa ukuran pellet yang lebih besar akan menurunkan nilai sudut tumpukan dengan nilai sudut tumpukan kecil akan lebih mudah dalam penanganan dan penyimpanan pada industri.

\section{Uji Kadar Air Pakan Pellet}

Nilai kadar air dari terkecil ke yang tertinggi secara berurutan adalah $7,78 \pm 0,03 \quad(\mathrm{P} 5), \quad 8,22 \pm 0,04 \quad$ (P6), $12,30 \pm 0,05 \quad(\mathrm{P} 7), \quad 13,72 \pm 0,27 \quad(\mathrm{P} 3)$, $13,98 \pm 0,16 \quad(\mathrm{P} 1), \quad 15,05 \pm 0,08 \quad(\mathrm{P} 2)$, $15,82 \pm 0,18$ (P8) dan 16,12 $\pm 0,29$ (P4).

Kadar air tertinggi dari pakan pellet pada jenis pellet sapi perah. Nilai kadar air seharusnya berbanding terbalik dengan nilai hardness. Semakin tinggi nilai kadar air, semakin rendah nilai hardness. Akan tetapi pada penelitian ini nilai hardness dan kadar air pada pakan pellet sapi perah sama-sama memiliki nilai tertinggi. Hal ini diduga karena pada bahan pakan pellet sapi perah menggunakan bahan pakan hijauan. Hijauan memiliki kandungan air dan serat kasar yang tinggi, sehingga apabila digunakan sebagai salah satu bahan pembuat pellet akan memiliki kandungan hardness dan kadar air yang tinggi. Menurut Retnani et al. (2009), semakin banyak kandungan kadar air ditentukan oleh bahan penyusunnya serta kelembaban disekitarnya.

Kadar air pellet yang baik yaitu dibawah 14\%. Ketaren (2010) melaporkan bahwa kadar air dibawah 10 persen lebih baik daripada kadar air diatas 14 persen. Kadar air yang terlalu tinggi akan menyebabkan penurunan kualitas mutu bahan pakan karena akan mudah terkontaminasi mikroba seperti jamur dan bakteri, selain itu akan membuat tekstur pellet lunak. Kadar air yang terlalu rendah akan mempengaruhi tekstur dan kekerasan pellet sehingga pellet akan mudah hancur. Rakhmawati et al. (2017) menyatakan bahwa pertumbuhan jamur dipengaruhi oleh kadar air selama penyimpanan. Trisulistiyani et al (2003) menyatakan 
bahwa jamur dan mikroba dapat ditekan aktivitasnya pada kadar air 12 - 14 persen. Faktor yang dapat mempengaruhi kadnungan kadar air salah satunya adalah faktor penyimpanan. Krisnan (2008) melaporkan bahwa kadar air pada ransum domba selama penyimpanan cenderung meningkat selama penyimpanan yaitu 12,5 - 14,1 persen. Nurhayatin dan Puspitasari (2017) melaporkan bahwa proses penyimpanan selama 6 minggu dapat mempengaruhi kadar air pakan dengan cara masuknya komponen air ke dalam pellet.

\section{KESIMPULAN}

Kesimpulan penelitian adalah pengujian kualitas pellet pada berbagai ternak dapat dilakukan secara fisik organoleptis, hardness dan kadar air. 
DAFTAR PUSTAKA

Ahmad, Z. R. 2009. Cemaran kapang pada pakan dan pengendaliannya. Jurnal Litbang Pertanian. 28(1):15-20.

Akbar, M. R. L., D. M. Suci dan I. Wijayanti. 2017. Evaluasi kualitas pellet pakan itik yang disuplementasi tepung daun mengkudu (Morinda citrifolia) dan disimpan selama 6 minggu. J. Buletin Makanan Ternak. 104 (2) : $31-48$.

Alviato, A., Muhtarudin dan Erwanto. 2015. Pengaruh penambahan berbagai jenis sumber karbohidrat pada silase limbah sayuran terhadap kualitas fisik dan tingkat palatabilitas silase. J. Ilmiah Peternakan Terpadu. 3(4) : $196-$ 200.

Behnke, K. C. 1996. Feed manufacturing technology : current issues and challenges. Anim. Feed Sci. Tech. $62: 49-57$.

Colovic, R., D. Vukmirovic, R. Matulaitis, S. Bliznikas, V. Uchockis, V. Juskiene and J. Lecvic. 2010. Effect of die channel press way length on physical quality of pellets cattle feed Food and Feed Research. $1: 1-6$.

Ilmiawan, T., B. Sulistiyanto dan C.S. Utama. 2015. Pengaruh penambahan pollard fermentasi dalam pellet terhadap serat kasar dan kualitas fisik pellet. Jurnal Litbang Provinsi Jawa Tengah. 13(2): $143-152$

Ismi, R. S., R. I. Pujaningsih dan S. Sumarsih. 2017. Pengaruh penambahan level molases terhadap kualitas fisik dan organoleptik pellet pakan kambing periode penggemukan. JIPT. 5 (3) : $58-63$.

Hidayah, N., I. P. Retno dan I. M. T. Baginda. 2017. Kualitas fisik organoleptic limbah tauge kacang hijau yang difermentasi menngunakan Trichoderma harzianum dengan aras starter dan lama pemeraman yang berbeda. Buletin Sintesis. 21(4): $21-25$.

Jaelani, A., S. Dharmawati dan W. A. cahyono. 2016. Pengaruuh tumpukan dan lama masa simpan pakan pellet terhadap kualitas fisik. ZIRAA'AH. 41 (2) : $261-268$.

Juniyanto, M. I. R., I. Susilawati, dan H. Supratman. 2015. Ketahanan dan kepadatan pellet hijauan rumput raja (Pennisetum purpuphoides) dengan penambahan berbagai dosis bahan pakan sumber karbohidrat. Jurnal Universitas Padjadjaran 4(2) : $1-13$.

Ketaren, P.P. 2010. Kebutuhan gizi ternak unggas di Indonesia. J. Wartazoa, 20 (4).

Krisnan,R. 2008. Perubahan karakteristik fisik konsentrat domba selama penyimpanan. Prosiding Seminar Nasional Teknologi Peternakan dan Veteriner. "Inovasi Teknologi Pendukung Pengembangan Agribisnis Peternakan Ramah Lingkungan. Bogor, $11-12$ November 2008. Hal. 491 - 497.

Krisnan, R. dan S. P. Ginting. 2009. Prospek penggunaan pakan komplit pada kambing tinjauan manfaatdan aspek bentuk fisik pada kambing serta respon ternak. J. Wartazoa. 19 (2) : $64-75$.

Krisnan, R. dan S. P. Ginting. 2009. Penggunaan Solid Ex-Decanter sebagai Binder Pembuatan Pakan Komplit Berbentuk Pellet : Evaluasi Fisik Pakan Komplit Berbentuk Pellet. Seminar Nasional Teknologi Peternakan dan Veteriner. Bogor, 13 - 14 Agustus 2009. Hal : 480 - 486. 
Kurniawan, H., R. Utomo dan L. M. Yusiwati. 2016. Kualitas nutrisi kepala (Cocos nucifera L.) fermentasi menggunakan Aspergillus niger. Buletin Peternakan. 40 (1) : $26-33$.

Midayanto, D. dan S. Yuwono. 2014. Penentuan atribut mutu tekstur tahu untuk direkomendasikan sebagai syarat tambahan dalam standar nasional indonesia. $\mathrm{J}$. Pangan dan Agroindustri. 2(4) : 259-267.

Muramatsu, K., A. Massuquetto, F. Dahlke and A. Maiorka. 2015. Factors that affect pellet quality : a review. J. of Anim Sci and Tech. 5 : 717 - 722. DOI: 10.17265/21616256/2015.09.002.

Nurhayatin, T. dan M. Puspitasari. 2017. Pengaruh cara pengolahan pati garut (Maranta arundinacea) sebagai binder dan lama penyimpanan terhadap kualitas fisik pellet ayam broiler. JANHUS. 1 (2) : $32-40$.

Rahmana, I., D. A. Mucra dan D. Febrina. 2016. Kualitas fisik pellet ayam broiler periode akhir dengan penambahan feses ternak dan bahan perekat yang berbeda. J. Peternakan. 13 (1) : 33 - 40.

Rakhmawati, Y. E., B. Sulistiyanto dan S. Sumarsih. 2017. Mutu fisik organoleptik pellet limbah penetasan dengan penambahan bentonit dan lama penyimpanan yang berbeda. Prosiding Seminan Nasional Teknologi Peternakan dan Veteriner, Bogor 8 - 9 Agustus 2017. p. 656 - 663. DOI: http://dx.doi.org/10.14334/Pros.Se mnas.TPV-2017-p.656-663

Retnani, Y., Y. Harmiyanti, D.A.P. Fibrianti dan L. Herawati. 2009. Pengaruh penggunaan perekat sintetis terhadap ransum ayam broiler. J. Agripet. $9: 1-9$.

Siregar, E. Alawiyah., H. Rusmarilin, dan L.N. Limbong. 2015. Pengaruh lama blansing dan jumlah gula terhadap mutu manisan basah sawi pahit. J. Rekayasa Pangan dan Pertanian. 3(2) : 1- 7 .

Solihin, Muhtarudin dan R. Sutrisno. 2015. Pengaruh lama penyimpanan terhadap kadar air kualitas fisik dan sebaran jamur wafer limbah sayuran dan umbi-umbian. J. Ilmiah Peternakan Terpadu. 3 (2): 48-54.

DOI: http://dx.doi.org/10.23960/jip t.v3i2.p\%25p

Suhendra, D., G. T. Anggiati, S. Sarah, A. F. Nasrullah, A. Thimoty dan D. W. C. Utama. 2015. Tampilan kualitas susu sapi perah akibat imbangan konsentrat dan hijauan yang berbeda. J. Ilmu-ilmu Peternakan. 25 (1): 42-46. DOI: 10.21776/ub.jiip.2015.025.01.06

Sulistyanto, B., C. S. Utama dan S. Sumarsih. 2016. Kualitas fisik organoleptik pellet limbah penetasan sebagai bahan pakan alternative pada aras penambahan bentonite yang berbeda. Prosiding Seminar Nasional Peternakan Berkelanjutan ke-8. Sumedang, 16 November 2016. Fakultas Peternakan, Universitas Padjajaran, Bandung. Hlm. 125-129.

Susilawat, I. dan L. Khairini. 2017. Introduksi pembuatan pellet hijauan pakan ternak ruminansia di Arjasari Kabupaten Bandung. J. Pengabdian Kepada Masyarakat. 1 (4) : $244-247$.

Syamsu, J. A. 2007. Karakteristik fisik pakan itik bentuk pellet yang diberi bahan perekat berbeda dan lama penyimpanan yang berbeda. $\mathrm{J}$. Ilmu Ternak 7 (2) : 128 - 134. 
Trisyulianti, E., Suryahadi dan V. N. Rakhma. 2003. Pengaruh penggunaan molases dan tepung gaplek sebagai bahan perekat terhadap sifat fisik wafer ransum komplit. Med.Pet. 26: 35-40.

Utama, C. S., Zuprizal, C. Hanim dan Wihandoyo. 2018. Isolasi dan identifikasi bakteri asam laktat selulolitik yang berasal dari jus kubis terfermentasi. J. Aplikasi Teknologi Pangan. 7(1): $1-6$.

Widiyastuti, T., C. H. Prayitno dan Munasik. 2004. Kajian kualitas fisik pellet pakan komplit dengan sumber hijauan dan binder yang berbeda. Anim Prod. 6: 43-48.

Wulandari, C. A., W. Hersoelistyorini dan Nurhidajah. 2017. Pembuatan tepung gadung (dioscorea hispidia dennst) melalui proses perendaman menggunakan ekstrak kubis fermentasi. Prosiding Seminar Teknologi Pangan, Universitas Muhammadiyah Semarang. 423 430. 